\title{
THE CONCEPT OF UNDERGROUND SPACE DEVELOP- MENT CONTROL IN SOUTHERN BADUNG AREA
}

\author{
Kadek Adi Kurniawan*, Rimadewi Supriharjo**, Eko Budi Santoso** \\ *) Master Student, Department of Architecture, Faculty of Civil Engineering and \\ Planning, Institut Teknologi Sepuluh Nopember, Indonesia \\ **) Lecturer, Department of Architecture, Faculty of Civil Engineering and Plan- \\ ning, Institut Tekologi Sepuluh Nopember, Indonesia \\ e-mail: adikurniawan2287@gmail.com
}

\begin{abstract}
Culture is a basic component of Balinese people's lives. All development activities have a purpose relative to the culture and values implicit in the concept of the traditional Balinese spatial plan. However, with changing times, there has been development which is not accommodated in the Balinese traditional spatial concept. This development is underground space development. As a result, the status of this development is pending, based on formal and non formal policies. Besides that, this development is unseen and therefore largely unknown and its suitability to environment hasn't been measured yet makes its sustainability status is in uncertain state. This paper addresses the concept of controlling the underground space development in the Southern Badung area based on Balinese traditional spatial concept and with a sustainable development approach.

The result identified that underground space development in Kuta village was dominated by commercial development as parking lots. There are three zones identified based on suitability for underground space development in Kuta village which are low suitability zone, medium suitability zone and high suitability zone. The evaluation in terms of culture and environmental suitability showed that there were seven priority criteria in formulating the concept of its development, namely: outside of open green place, had mitigation system for disasters, outside of Tahura Ngurah Rai, outside of the coast border, outside of and not directly adjacent to the Holy Region, outside of and not directly adjacent to graves of Kuta. The main result of this research is a concept of underground space development control to create sustainable tourism in Kuta village.
\end{abstract}

Keywords: underground space development control, Balinese traditional spatial planning, sustainable development 


\begin{abstract}
ABSTRAK
Budaya merupakan falsafah dasar kehidupan masyarakat Bali. Segala aktivitas pembangunan mengacu pada nilai-nilai budaya yang tercermin dalam konsep penataan ruang tradisional Bali. Namun seiring dengan perkembangan jaman terdapat pembangunan yang tidak terakomodasi di dalam konsep tata ruang tradisional Bali. Pembangunan ini adalah pembangunan ruang dalam bumi. Akibatnya, status pembangunan ini masih menggantung dalam kebijakan formal maupun non formal. Disamping itu, kesesuaian pembangunan ini terhadap kondisi fisik dasar lingkungan setempat belum terukur secara pasti sehingga belum dapat dipastikan keberlanjutannya secara lingkungan. Berangkat dari permasalahan tersebut, dibutuhkan konsep pengendalian pembangunan ruang dalam bumi di Kawasan Badung Selatan yang berdasarkan tata ruang tradisional Bali dengan pendekatan Pembangunan Berkelanjutan.

Hasil penelitian mengidentifikasi bangunan ruang dalam bumi di Desa Adat Kuta didominasi oleh bangunan komersil dengan pemanfaatan sebagai ruang parkir. Teridentifikasi 3 zona kesesuaian pembangunan ruang dalam bumi di Desa Adat Kuta, yaitu Zona Kesesuaian Rendah, Zona Kesesuaian Sedang dan Zona Kesesuaian Tinggi. Hasil evaluasi kesesuaian budaya dan lingkungan menunjukkan bahwa terdapat 7 kriteria yang menjadi prioritas dalam perumusan konsep pengendaliannya yaitu berada di luar ruang terbuka hijau, memiliki sistem mitigasi bencana, berada di luar Tahura Ngurah Rai, berada di luar Kawasan Sempadan Pantai, berada di luar dan tidak berdampingan secara langsung dengan Kawasan Tempat Suci, berada di luar dan tidak berdampingan secara langsung dengan Kawasan Suci, berada di luar dan tidak berdampingan secara langsung dengan Kawasan Setra/Kuburan Desa Adat Kuta. Hasil dari penelitian ini adalah konsep pengendalian pembangunan ruang dalam bumi untuk mewujudkan Desa Adat Kuta sebagai Kawasan Pariwisata berkelanjutan.
\end{abstract}

Kata kunci: pengendalian pembangunan ruang dalam bumi, tata ruang tradisional Bali, pembangunan berkelanjutan

\title{
INTRODUCTION
}

Spatial planning policy implemented in Bali could not be separated from culture as its basic development (Suartika, 2010). The tradition of Balinese culture is embodied in controlling the behavior of Hindus' religious practices based on three elements, namely; 1). Tatwa or philosophy; 2). Susila or ethics; 3). Upacara or rituals (Parisada Hindu Dharma, 1978:16 in Dwijendra, 2003). Then Meganada (1990:44) in Dwijendra (2003), has explained that Balinese culture could not be separated from the values of Hindu religion that have three basic elements (tatwa, susila, upacara) for its people to reach their purpose (Dharma), which is to be called in Weda: "Moksartham Jagadhita Ya Ca Iti Dharma"

The implementation of spatial control faces legal sanctions in case of breach. In utilizing land in Bali, its conformation was controlled tightly by the awareness of 
people to protect the cultural elements which might be close to defacement. Particularly, this relates to several external factors that are caused by development activities that happened around a site (Suartika 2005 in Suartika, 2010). As a proof of Suartika's statement above, the implementation concepts of traditional Balinese spatial planning and the philosophy of the culture have been accommodated in Spatial Plan of Bali province that is quoted in Perda No. 16 Tahun 2009.

The development of the tourism sector in the Province of Bali, mainly in the Southern Badung area, had caused a wide and vast development especially for infrastructure. As an example, there was the Underpass Simpang Dewa Ruci that officially opened in August 2013 in Kuta Village, Southern Badung Area. The development of Underpass Simpang Dewa Ruci was one of underground space development where this kind of development was not yet set in the formal spatial policy of Bali Province. The current regional planning policy of Bali Province, as the legal protection of its development, is regulating only vertical development above the ground by setting a limit on the maximum height of buildings (15 meters tall maximum).

One of the reasons why underground space development control is not accommodated yet in the Regional Spatial Plan (RTRW) of the Province of Bali is because this development is not clearly explained in the concept of Balinese traditional spatial planning. The development concepts of Tri Angga and Sanga Mandala which oriented in axes of north-south and east-west are much more directly applicable in managing horizontal development above the ground. Whereas vertical development is in the concept of Balinese traditional spatial planning just for vertical development above ground by means of the concept of Tri Loka.

The concept of underground space development control in Bali was not only studied through social and cultural perspective (traditional spatial planning) but also, even more likely, to sustainable development concept. The Balinese traditional spatial planning itself had been given as the basic approach toward sustainable development through Tri Hita Karana concept which was emphasized the balance between physical development and environment. There were several weaknesses of underground space development in perspective of environment management, as mentioned below:

1. Reduced soil ability and quantity to absorb ground water

2. The elevation level of undeground space is lower than its suround area, leads the escalation of its flood vulnerability.

3. Space reduction to collect underground water, limitated underground water availabitlity.

The problem is how Balinese traditional spatial planning and sustainability development concept accommodate the underground space development until it able to move along with today's development. Functional marriage between tourism sectors with Balinese culture is inevitable and the main problem is how to eliminate the culture transformation without reducing the importance of tourism development especially in Southern Badung Area as the center of tourism development in Bali.

The underground space development wich is not accommodated yet in formal spatial planning policy of Bali causing the regulation of this development is in vague state. Underground space development did not explicitly explained in Balinese tradi- 
tional spatial planning and has high environment vulnerability. But in other side it has already existed in Kuta, southern Badung area without any clear legal regulation. Formulation of the underground space development control is needed to manage its presence in the future and give it a clear status from the cultural and eviromental perspectives.

The research question is what criteria that could be utilized as control instrument of the underground space development based on Balinese traditional spatial planning and sustainable development concept?

\section{THEORY / RESEARCH METHODS}

Development of underground space has benefits that turn it as the main choice when compared to above ground space development. Godard, 2004 stated there were at least four aspects of benefits of undergrpund space development. Such benefits include:

1. Utilization of underground space allows a facility to built where surface space is impossible to accommodate such limited land surface or rejection of society

2. Underground space provides protection from climates

3. The structure of underground space help provide protection for natural vegetation

4. Providing independence for 3 dimensional planning because it is not affected by the contour of the ground surface

Kass and Lees, 1997 stated there are four constraints in the underground space development: zoning, floor area ratio, the historic site and Geotechnical and structural considerations. Zoning and floor area ratio are limitations deliberately created to organize the development of underground space while the historic sites and Geotechnical and structural considerations are a natural boundaries that are closely related to the carrying capacity of the environment.

Pinzone et al, 1997 stated that in relation to sustainable development, underground space development has some issues, namely below:

1. Climate Change and Green House Effect

2. Maintenance of ecological processes

3. Biodiversity

4. Equality between generations

5. Precautionary Principle

6. Assessment of environmental resources

In addition to 6 aspects as described above, Pinzone et al, 1997 described another issues that directly linked to underground space development. Such issues include:

1. Geological Suitability

2. Seismic activity

3. Hydrogeological

4. Water and Air Pollution

5. Flora and Fauna 
6. Psychological Factor

7. Health and Safety

\section{Research Methods}

The purpose of this study is to formulate the concept of underground space development control based on Balinese traditional spatial planning and sustainable development concept. Research is departing from the phenomenon and the empirical fact that occurred on the field with a rationalistic approach. The study begins by identifying the type and distribution of the underground space utilization that has already existed in Kuta. This Identification purposed to inventory the presence of underground space development in Kuta and giving picture of its utilization diversity. The next step is evaluation of those identified underground space utilizations by using awig-awig (custom development regulation) of Kuta. This evaluation purposed to acquaint suitability and position of indentified underground space utilizations to awig-awig of Kuta as the representation of Balinese traditional spatial planning in Kuta. The cultural evaluation then followed by the assessment of indentified underground space utilizations to environmental impact and suitability. This assessment purposed to identify its suitability to environment and resilience of disaster conditions. Result of cultural evaluation and environmental suitability analysis are then used to formulate the underground space development control criteria. Main criteria to concept formulation of the underground space development control in Kuta were the result of this analysis. These criteria were taken from stakeholders (group or individu who had the most power and interest in decicion making of development regulation in Kuta) perspective. The final step is formulating the concept of underground space development control in Kuta (South Badung Area) by using the main criteria. This concept contained zoning map and zoning text as the implementation instrument, to make this concept more applicative to underground space development in Kuta.

\section{RESULTS AND DISCUSSION}

\section{The Identification of Distribution and Type of Underground Spaces Utilization In Kuta.}

The identification of underground space distribution and utilization in Kuta purposed to acquaint and inventory:

1. Commercial and non commercial (aboveground) activities which had developed their underground space to support their main activities

2. Kinds of underground space activities in Kuta

3. Location of identified activities which had developed their underground space

Distribution of the underground space utilization in Kuta can be seen in Figure 1. Identification of distribution and type of underground space utilization in Kuta was conducted by using field observation technique by examined all building in $\mathrm{Ku}-$ 
ta. Every buildings that utilize their underground space were recorded to distinguished their type and distributions. The results of this identification are as mentioned below:

1. There were 35 buildings in Kuta that utilized their underground space as their above ground supporting space. These 35 buildings consist of 34 comercial buildings and 1 non commercial building (underpas Dewa Ruci). Most of them were located at Pantai Kuta Street, Kartika Plaza Street and Legian Street.

2. The 34 commercial buildings covered of 26 hotel and restourants, 2 bank and credit institutions, 4 malls and commercial center, 1 shops complex, and 1 tour and travel service.

3. Most of identified buildings ( $89 \%$ of them) utilized their underground space as parking lots. The rest were as mix use (as parking lots, shops, management office, praying room, ATM center) and underpass. Space avalaibility for parking lots was one of main problem in Kuta as a tourism region. Investors and hotel owners were seeking possible spaces to be developed as vertical development were limited to 15 meters tall and horizontal development was likely impossible due to high building density and unreachable land price.
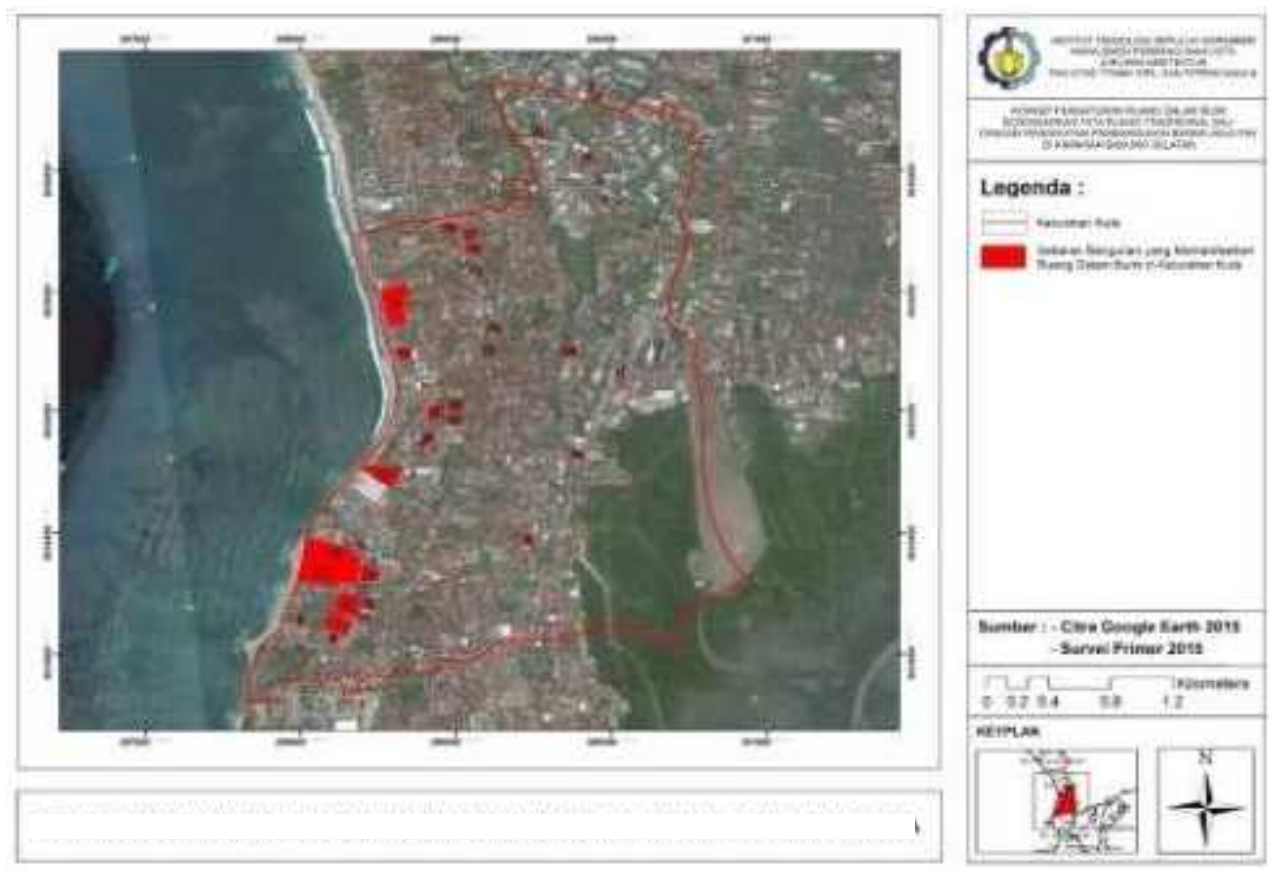

Figure 1. Map of Underground Buildings Distribution in Kuta Source: primary survey, 2014

The result of this identification would be evaluated to awig-awig Kuta to examine their suitability and position to Balinese traditional spasial planning perspective in Kuta. The result of this evaluation pictured the type of underground space 
utilization that able to be developed in the future in Kuta based on its cultural perspective.

\section{Suitability Evaluation of Underground Space Utilization to Traditional Spatial Planning in Kuta}

As mentioned above, all 35 identified buildings suitability was evaluated to traditional spatial planning using awig-awig of Kuta. Awig-awig is a custom or traditional law of traditional village in Bali regulated building and land development, tradition activities, and social interaction. Awig-awig is the implementation of Balinese traditional spatial planning concept therefor suitability evaluation of underground space utilization in Kuta was based on this custom regulation.

Based on content analysis result using in-depth interview technique with Bendesa adat (Chief of Kuta village) and Majelis Utama Desa Pekraman (Prime Council of Traditional Village) of Bali as the respondends, underground space development (as identified before) did not mentioned in awig-awig of Kuta.This because underground space utilization when awig-awig of Kuta village was agreed and applied by its people was significantly different with what happened today. The utilization of underground space at that time were only for fresh water development such as well and as temporary space for funeral before the body burned down in ngaben ceremony, not as space for human activities. At that time, spaces under the ground were not considered and recognized as spaces for human activities. Because of this condition, utilizations of the underground building did not mentioned in awig-awig of Kuta. In other words awig-awig of Kuta could not justified underground buildings and other utilizations's status. Revision of awig-awig was not an urged act as there were no any complaints coming from people of Kuta related to underground space utilization. The revision necessarily needed if there were objections to awig-awig that need new approbations. Even it seems outdated (at some points) and did not accommodate development pace, awig-awig of Kuta is still applied by people of Kuta as their basic tradition regulation because at other points awig-awig regulated aspects that will never changed like regulation on traditional activities, society interactions and traditional ceremony days.

Because of that weakness, the suitability evaluation of the underground space utilization could not be conducted by using Awig-Awig of Kuta. Based on cultural perspective in Kuta, underground space utilization status could not be justified as permitted, limited or interdicted development. But there was certain regulation mentioned in awig-awig related to underground space development. Awig-awig has substanstion that regulated distiguished sacred area for tradition and religion (Hindu) activites such as temples, cemeteries, and melasti (one of concatenation ceremony before Nyepi) area. These areas were mentioned as Kawasan Tempat Suci (sacred place), Kawasan suci (sacred area) and Setra (cemetery) as can be seen in Figure 2. Activities that did not related to Hindu or Kuta's tradition were prohibitted in these areas. Therefor, any underground space development for all activities could not be conducted in these areas. The underground space developments were allowed outside of Kawasan Suci, Kawasan Tempat Suci and Setra but with approbation people of Kuta. Approbiaton is one of the most important aspects in the implementation of 
awig-awig because awig-awig was made from consensus of its people. Therefore the concept of the underground space development control in Kuta has to accommodate its people perspective.

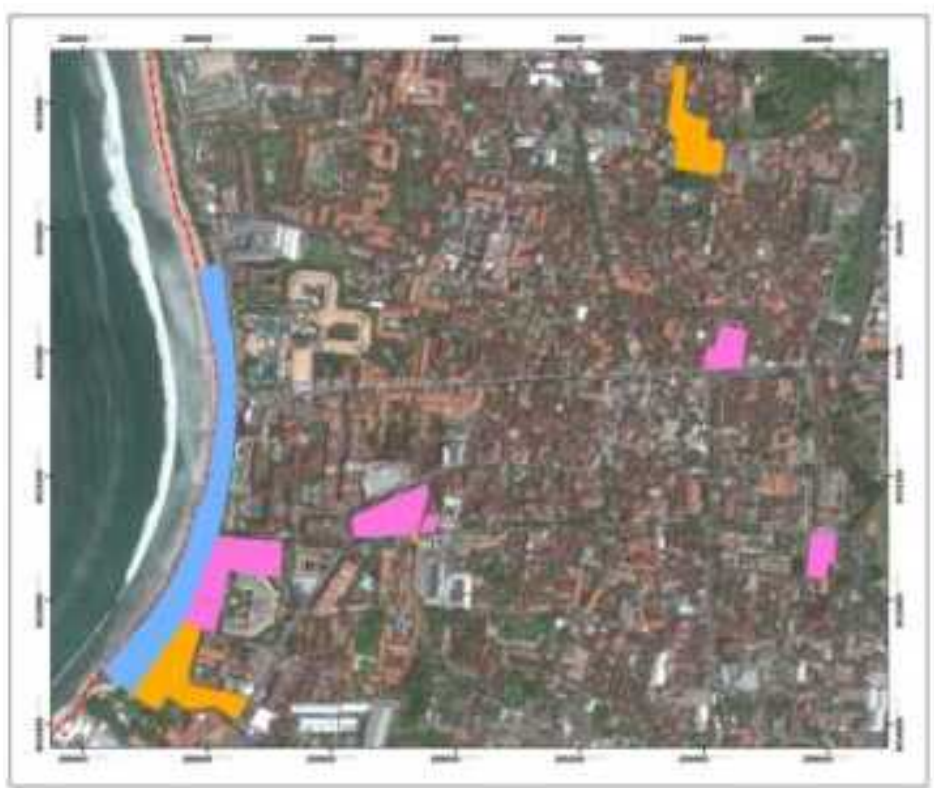

DETA KALIA CAN TEMBAT CIICI RAM KALMA EAH CIICI

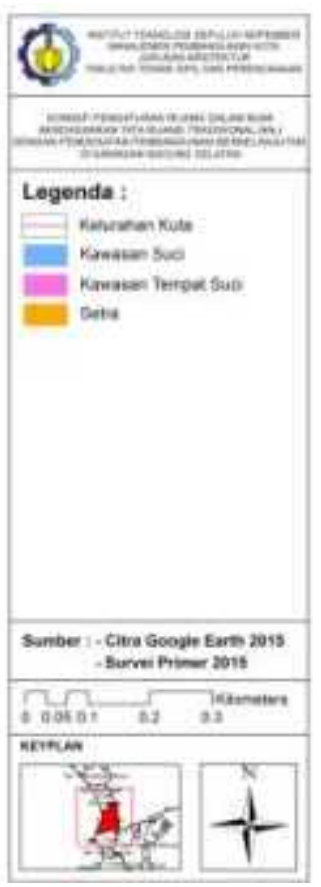

Figure 2. Map of Kawasan Suci, Kawasan Tempat Suci and Setra in Kuta Source: primary survey, 2014

As seen in Figure 2, there were a lot of possible spaces to be explored as spaces for underground development in Kuta. But since awig-awig of Kuta did not regulated underground space development, the concept of this development control more relied on sustainable development concept outside of Kawasan Suci, Kawasan Tempat Suci and Setra. In this research, formulation of the concept of underground space development control in Kuta was based on its resilience to natural disaster and possible impact of potensial underground space development in the future.

\section{Impact and Suitability Analysis of Environment in Kuta to Accommodate Un- derground Space Development}

Inventory of potensial underground space utilizations in Kuta was needed to identify possible activities that could be held in underground space in the future. Underground space development control did not just regulate nowadays utilizations but also potensial utilizations in the future to keep the sustainability of this type of development.

Table 1 as seen below is a list of potential activities that utilized underground space in Kuta with possible impact to environment whether it is inside or outside of 
Buildings. Except as utilities function, others space functions has numbers of potential harm to their environment. Therefor, control of these space functions and activities is needed to keep the sustainability of this development since we could not obstructed progression development of an area.

Table 1. The Inventory of Potential Activities Using Underground Space in Kuta

\begin{tabular}{|c|c|c|c|}
\hline $\begin{array}{l}\text { Space Func- } \\
\text { tion }\end{array}$ & Activities & $\begin{array}{l}\text { Impacts of Internal } \\
\text { Environment }\end{array}$ & $\begin{array}{c}\text { Impacts of External } \\
\text { Environment }\end{array}$ \\
\hline Utilities & $\begin{array}{l}\text { 1. Power and Electricity } \\
\text { 2. Telecommunication } \\
\text { 3. Drainage } \\
\text { 4. Waste Water } \\
\text { 5. Gas }\end{array}$ & & $\begin{array}{l}\text { The contamination of } \\
\text { underground water } \\
\text { caused by waste lea- } \\
\text { kage }\end{array}$ \\
\hline Tourism & $\begin{array}{l}\text { 1. Restourant } \\
\text { 2. Night Club/Bar } \\
\text { 3. Hotel }\end{array}$ & $\begin{array}{l}\text { - Limited air circula- } \\
\text { tion } \\
\text { - Needs extra energy } \\
\text { to control room } \\
\text { temperature } \\
\text { - Limited natural } \\
\text { illumination }\end{array}$ & $\begin{array}{l}\text { - increase underground } \\
\text { water consumption } \\
\text { - disrupt the flow of } \\
\text { underground water } \\
\text { - Increase waste produc- } \\
\text { tion } \\
\text { - Evoke new transporta- } \\
\text { tion generator }\end{array}$ \\
\hline Settlement & $\begin{array}{l}\text { 1. Store Room } \\
\text { 2. Garage }\end{array}$ & $\begin{array}{l}\text { - Limited Air circula- } \\
\text { tion }\end{array}$ & $\begin{array}{c}\text { - Disrupted the flow of } \\
\text { underground water }\end{array}$ \\
\hline $\begin{array}{l}\text { Trade and } \\
\text { Services }\end{array}$ & $\begin{array}{l}\text { 1. Supermarket } \\
\text { 2. Storage } \\
\text { 3. Waste Water Instala- } \\
\text { tion }\end{array}$ & $\begin{array}{l}\text { - Limited Air circula- } \\
\text { tion } \\
\text { - Needs extra energy } \\
\text { to control room } \\
\text { temperature }\end{array}$ & $\begin{array}{l}\text { - increase underground } \\
\text { water consumption } \\
\text { - disrupt the flow of } \\
\text { underground water } \\
\text { - Increase waste produc- } \\
\text { tion } \\
\text { - Evoke new transporta- } \\
\text { tion generator }\end{array}$ \\
\hline $\begin{array}{l}\text { Recreation } \\
\text { Facilities }\end{array}$ & $\begin{array}{l}\text { 1. Cinema } \\
\text { 2. Gymnasium }\end{array}$ & $\begin{array}{l}\text { - Limited Air circula- } \\
\text { tion } \\
\text { - Needs extra energy } \\
\text { to control room } \\
\text { temperature }\end{array}$ & $\begin{array}{l}\text { - increase underground } \\
\text { water consumption } \\
\text { - disrupt the flow of } \\
\text { underground water } \\
\text { - Increase waste produc- } \\
\text { tion } \\
\text { - Evoke new transporta- } \\
\text { tion generator }\end{array}$ \\
\hline Transportation & Subway & $\begin{array}{l}\text { - Limited Air circula- } \\
\text { tion } \\
\text { - Needs extra energy } \\
\text { to control room } \\
\text { temperature } \\
\text { - Vibrations and noises }\end{array}$ & $\begin{array}{c}\text { - disrupted the flow of } \\
\text { underground water }\end{array}$ \\
\hline
\end{tabular}


All addition activities as mentioned in Table 1 above have potential to increase harms to its environment. This situation was currently handled by Kuta. Potential harms that might get bigger by presence of underground space development in Kuta district are as follow:

1. Increase potential of sea intrusion.

Escalation of sea intrusion in Kuta district was because the enhancement of underground water consumption and exploitation around coastal area. This exploitation dropped underground water level and caused sea water seeps in and mixed with underground water inside water basin.

2. Influence the underground water quality

Water quality research of Badung regency in 2014 found that the water qualities of Kuta district (divided into Kuta 1 and Kuta 2) were in good (Kuta 1) and medium status (Kuta 2). These underground water qualities might have changed if there were underground water contamination caused by the escalation of human activities. Underground space utilization affected the escalation of waste production as it enhanced possible spaces for human activities which potentially influenced underground water qualities in Kuta.

3. Increase potential of waste water pollution

Most of hotels in Kuta were still using on-site system to manage their waste water which caused their liquid waste could not be supervised directly by The Government. This condition might cause high pollution because of the weakness of Government supervision. Underground space utilization as commercial activities that using on-site system as their waste water management increased potential of enviroment pollution because it enhanced space for human activities to produced more waste water.

4. Increase transportation load

The underground space utilization like commerce service facilities and tourism accommodation could increase transportation load in district of Kuta. Addition activities under the ground would generate mass and movement of people and vehicles. Congestion was the main problem in transportation system in Kuta mainly in holidays because the road capacity could not accommodate the vehicle volume especially along Pantai Kuta and Legian street.

5. Increased potential of critical area

Critical area that happened in Kuta was caused by abrasion. Addition activies under the ground around coastal areas would increase the risk of abrasion and also added burdens on the coastal environment in facing the abrasion.

Environmental impacts above pictured us for what kind of activities that allowed or possible to conduct under the ground. Activities under the ground that could generate huge mass of people, huge transportation movement and exploited underground water were not allowed. These kinds of activities are related directly to massive scale activities. In other words all acitivities as seen in table 1 are possible to be conducted under the ground but are not allowed in massive scale. Bigger the activities mean bigger the mass generated, larger underground water consumptions and evoked bigger transportation movement. That's why limitated the scale of activities is the key to control underground space development. 
Activities under the ground inside the coastal border are also interdicted to avoid potential harms from abration. Any addition buildings inside coastal border are interdicted to lightened environment burden in facing the abration.

After kinds of activities that allowed to be conducted under the ground were identified, the area to conduct that acitivities must be justified. Permitted, limited, conditional or prohibitted areas for underground space development beyond Kawasan Suci, Kawasan Tempat Suci and Setra must clearly be justified. There were 6 variables that were used to justify areas for underground development. These 6 variables were used to acquaint their carrying capacity and resilience to natural disasters.

1. Seismic activity

Based on disaster mitigation planning of Badung regency 2014-2018, Kuta entirely has low potential danger of seismic activity. Underground building could be functioned as shelter when earth quake happened because soils around the structures absorbed shock and vibes from the quake. But its isolation character gave another potential danger because limited access to surface ground would trap occupants inside the buildings if that access were blocked by ruins or debris. Therefor in high risk area, underground buildings must be equipped with fine and safe access to surface ground.

2. Tsunami

Kuta district has high potential risk level of tsunami. There were 655,65 hectares areas or about $89 \%$ of Kuta District that would directly affected to tsunami. This level of potential risk would be escalated as it closer to the coastal area (Kuta Beach). Underground space development status inside an area that directly affected to tsunami was justified by their risk level. Underground space development would be interdicted if they conducted in high risk level area and would be allowed in low risk level area. This was because underground building has isolation character by it limited access to surface and makes potential risk disaster bigger then aboveground building.

3. Abrasion

Kuta beach was a vulnerable area to abrasion and high wave. Abrasion shore was very dangerous, especially for nearby buildings. The the strategic environmental study of Badung regency in 2013 mentioned that abrasion would cause shorelines narrowed increasingly and if did not resolved eventually low areas would sinked. It makes building under the ground nearby Kuta Beach were interdicted to built.

4. Flooding

Based on Study of Development Planning for Natural Resources and Environment of Badung Regency in 2009, Kuta was a district with the highest risk potential of flood in Badung regency. Underground buildings had a big risk if they were built inside the highest flood risk area. This was because the underground buildings position was lower than surround area which caused the water surface would flowed into underground building easily. It makes underground buildings were interdicted to built inside a high risk flood area and must be equipped with mitigation system if they were built beyond high risk flood area. 


\section{Green Open Space}

Kuta Village has 3.48 Hectares of green open space which are in forms of green belts, city parks, park in tourism destinations, city forest, grave yard, public open space and open space parking area. These green open spaces are utilized as water catchment area so the underground develepmont are prohibited to conducted inside green open space.

6. Protected Area

Protected area in Kuta Village is Tahura Ngurah Rai. Tahura Ngurah Rai is a green open space of mangroves located at Benoa Bay Area purposed to protect the coastal area inside Benoa Bay Area. Underground development are restricted inside this area.

Maps of those 6 variables were superimposed to acquaint Kuta's resiliensce. Superimpose analyisis pictured us suitability and resilience of Kuta to accommodate underground space development. There were 3 zones (as can be seen in Figure 3) that divided Kuta based on its resilience and suitability as the result of superimpose analysis. These zones as mentioned below.

1. Low Suitability zone. This zone has the highest risk of flooding, highest risk of tsunami, low earthquake risk, highest risk of abrasion, Kawasan Suci, Kawasan Tempat Suci, and Setra. The underground space development in this zone faced highest risk to disaster especially for human activites. This condition prohibited underground development for human activities at all scales but still possible for utilities. Restriction for human activities under the ground in this zone also served as mitigation system in Kuta.

2. Medium suitability zone. Half of this zone was on high risk of flooding area makes underground buildings inside this zone for human activities were vulnerable to be built. There were also Kawasan Suci and Setra located in this zone made underground development limited to outside these sacred areas. But in other hand this zone has medium risk of tsunami and low risk of earthquake. Potential risk to natural disaster were lower then the Low Suitability Zone. Underground developments were possible in this zone but with some restrictions such: equipped with mitigation system, outside Kawasan Tempat Suci and Setra, and the activities were not the potential activities which caused mass concentration of people.

3. High Suitability zone. This zone has low risk of earthquake, medium risk of tsunami and free from potential of flooding. Underground development in this zone has highest possibility to be built but most of this zone was part of Tahura Ngurah Rai as the green open space of Kuta. Any developments inside of Tahura Ngurah Rai were prohibited to maintain its function as water catchment area. That space limitation caused this zone has low potential to be developed even it faced lowest risk of disaster 


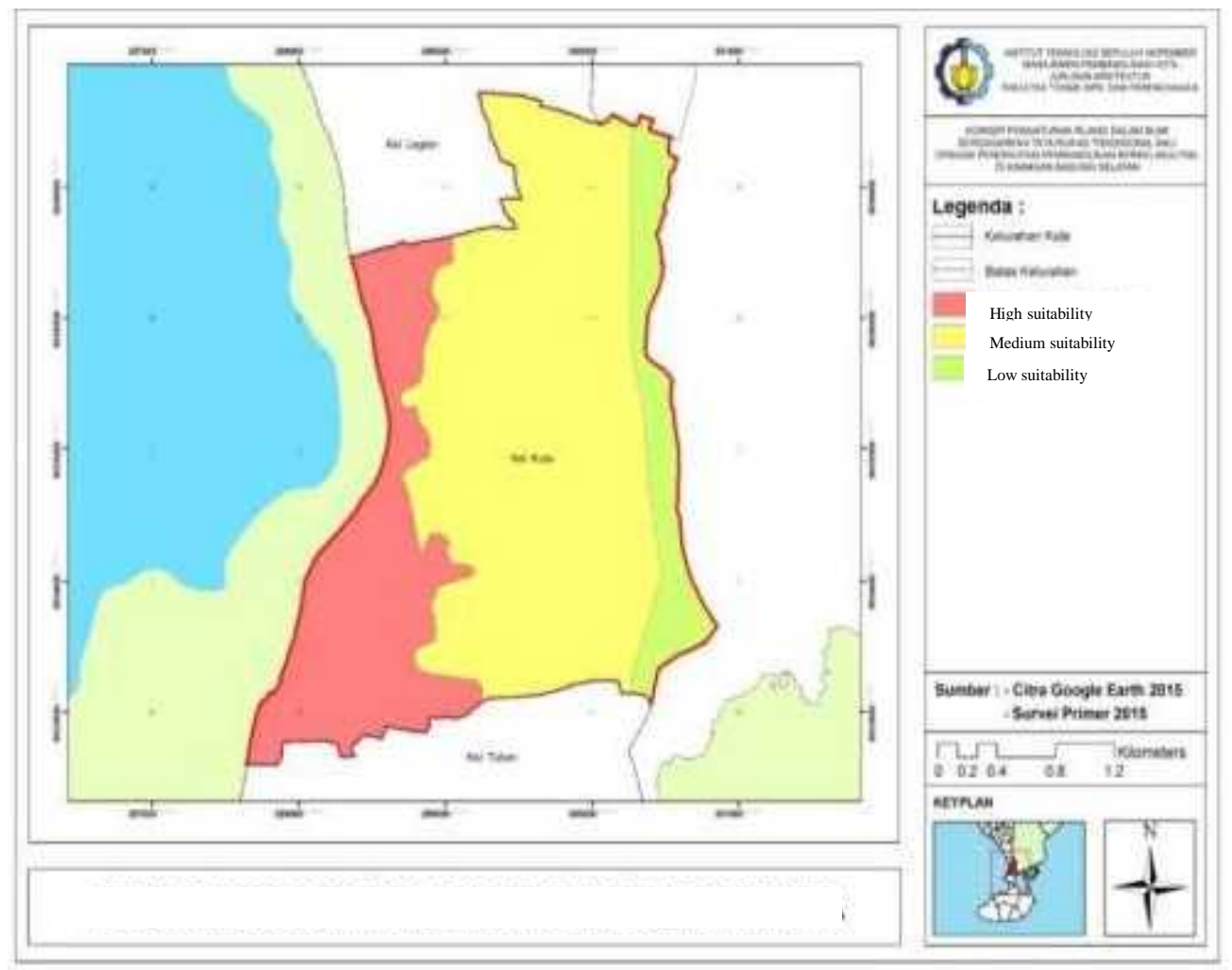

Figure 3. Map of Land Suitability Zone in Kuta Source: Superimpose analysis, 2014

\section{Criteria Analysis of Underground Space Development Control Formulation}

There were 17 criteria that had been formulated based on the results of cultural evaluation and environment suitability of underground space development in Kuta as seen in Table 2. These criterias were divided into 5 cultural criteria and 12 environmental criteria. These criteria were the initials criteria to formulate the concept of underground space development control in Kuta. These initial criteria require stakeholders approbation in term to accommodate their perspectives especially bendesa adat Kuta as the representation of Kuta Village people. There were 3 main stakeholders in this research. These stakeholders were Regional Development and Planning agency of Badung regency, Environment Agency of Badung regency, and Bendesa Adat of Kuta. These stakeholders were group or individual who has the most power and interest in decicion making of development regulation in Kuta. Through approbation of these stakeholders, results of research had significant justification to be implemented in Kuta. 
Table 2. The Criteria of the Underground Space Development Control based on Cultural Evaluation and Environment Suitability of Kuta.

\begin{tabular}{|c|c|c|}
\hline No & Analysis Process & $\begin{array}{l}\text { Criterias } \\
\end{array}$ \\
\hline 1 & $\begin{array}{l}\text { Suitability Evaluation of } \\
\text { Underground Space Utiliza- } \\
\text { tion to Traditional Spatial } \\
\text { Planning in Kuta }\end{array}$ & $\begin{array}{l}\text { 1. underground activities are not Hindu's activities } \\
\text { and tradition of Kuta people } \\
\text { 2. Activities that are still linked to the tradition of } \\
\text { Kuta People could be organized under the ground } \\
\text { under Kuta people approbation } \\
\text { 3. Underground space development are out and not } \\
\text { directly adjacent to Kawasan Tempat Suci } \\
\text { 4. Underground space development are out and not } \\
\text { directly adjacent to Kawasan Suci } \\
\text { 5. Underground space development are out and not } \\
\text { directly adjacent to Setra }\end{array}$ \\
\hline 2 & $\begin{array}{l}\text { Impact and Suitability } \\
\text { Analysis of Environment in } \\
\text { Kuta to Accommodate Un- } \\
\text { derground Space Develop- } \\
\text { ment. }\end{array}$ & $\begin{array}{l}\text { 1. The underground development priority is as the } \\
\text { utilities spaces (Clean water networks, electrics } \\
\text { networks, drainage networks, waste water net- } \\
\text { works, gas networks, transportation networks) } \\
\text { 2. Activities inside of the underground space are } \\
\text { supporting their above activities. } \\
\text { 3. Activities inside of the underground space should } \\
\text { be harmonius with their above activities } \\
\text { 4. Activities inside of the underground space are not } \\
\text { high transportation generator activities } \\
\text { 5. Activities inside of the underground space are not } \\
\text { generate mass concentration of people } \\
\text { 6. Activities inside of the underground space are not } \\
\text { exploit underground water. } \\
\text { 7. Activities inside of the underground space are not } \\
\text { increase the energy load. } \\
\text { 8. Have special parking place to supporting activities } \\
\text { which held under the ground } \\
\text { 9. Located just outside of Green Open Space } \\
\text { 10. Located just outside of Tahura Ngurah Rai } \\
\text { 11. Located just outside of the Coastal Border Region } \\
\text { 12. Equipped with mitigation system }\end{array}$ \\
\hline
\end{tabular}

Based on stakeholder approbation by using AHP (Analytical Hierarchy Process) as seen in figure 4, there were seven main criteria that had been elected for the formulation of underground space development control in Kuta. All the 7 main criteria were as followed;

1. Located just outside of Green Open Space

2. Located just outside of Tahura Ngurah Rai

3. Located just outside of the Coastal Border Region

4. Equipped with mitigation system.

5. Underground space development are out and not directly adjacent to Kawasan Tempat Suci 
6. Underground space development are out and not directly adjacent to Kawasan Suci

7. Underground space development are out and not directly adjacent to Setra

The result of main criteria analysis above indicated the priority criterias for underground space development based on stakeholder perspective. On the Stakeholders's perspectives, criteria that represented location of underground building were more important criteria then the criteria that represented what kinds of activities that possibly conducted under the ground. Any kinds of activities were not priority on their perspectives, but their locations were. So then in the formulation of the concept of underground development control in Kuta, was more emphasized on locational criterias. The main criteria that had been determined were then used as inputs in the formulation of concept of the underground space development control in Kuta.

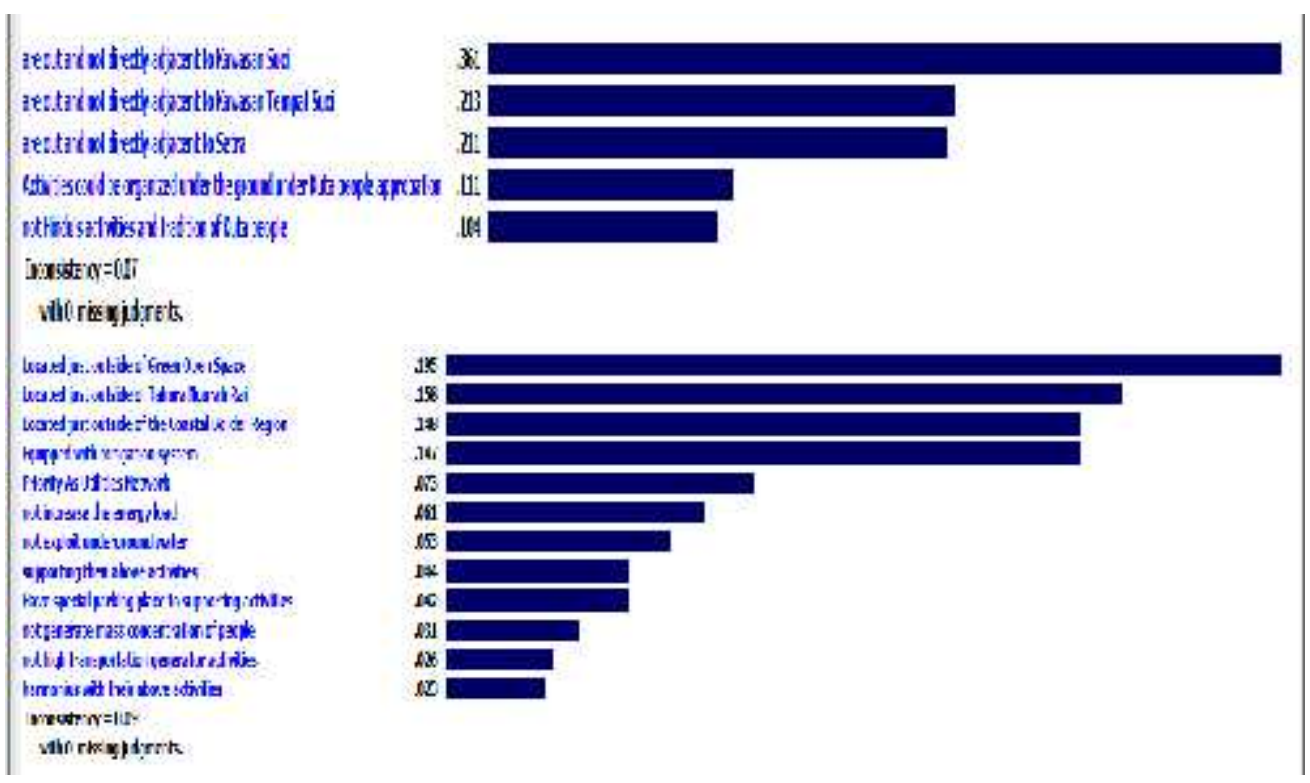

Figure 4. AHP Results to Determinate Main Criteria of Underground Space Development Control Concept in Kuta Source: AHP result, 2014

\section{The Concept of Underground Space Development Control Based on Balinese Traditional Spatial planning and Sustainable Development Concept}

Analysis in formulation of the concept of underground space development control in Kuta was using Content Analysis. Retrieval of data analysis was done by using indepth interviews. All Stakeholders were asked for their perspectives on the initial concept of the underground space developmet control in Kuta for each zone as shown in Figure 3. This initial concept was made upon 7 main criteria that had been elected before. 
The concept of underground space development control in Kuta was the development control instrument to achieve sustainable Tourism in Kuta. This concept emphasized on controlling the utilization of underground space that could improve the quality of tourism area in Kuta. With this concept of underground space development control, the underground space utilization in Kuta could be monitored so as to created new space to support its above ground activities as they were difficult to grown laterally and upwards

The concept of underground space development control above was then translated into a matrix as shown in Table 3 . Table 3 is the initial concept of underground space development control based on 7 main criterias that had been elected before. The initial concept would then be submitted back to the stakeholders to acquaint their perspectives on it.

Table 3. The Initial Concept of Underground Space Development Control in Kuta

\begin{tabular}{|c|c|c|c|c|}
\hline \multirow{2}{*}{$\begin{array}{l}\text { Space Func- } \\
\text { tion }\end{array}$} & \multirow{2}{*}{$\begin{array}{l}\text { Type of Under- } \\
\text { ground Acitvity }\end{array}$} & \multicolumn{3}{|c|}{ Zones } \\
\hline & & $\begin{array}{l}\text { Low Suita- } \\
\text { bility Zone }\end{array}$ & $\begin{array}{c}\text { Moderate Sui- } \\
\text { tability Zone }\end{array}$ & $\begin{array}{l}\text { High Suita- } \\
\text { bility Zone }\end{array}$ \\
\hline \multirow[t]{6}{*}{ Utility } & Power and Electricity & $\mathrm{P}$ & $\mathrm{P}$ & $\mathrm{P}$ \\
\hline & Clean Water & $\mathrm{P}$ & $\mathrm{P}$ & $\mathrm{P}$ \\
\hline & Telecumication & $P$ & $\mathrm{P}$ & $\mathrm{P}$ \\
\hline & Drainage & $\mathrm{P}$ & $\mathrm{P}$ & $\mathrm{P}$ \\
\hline & Waste Water & $\mathrm{P}$ & $\mathrm{P}$ & $\mathrm{P}$ \\
\hline & Gas & $P$ & $\mathrm{P}$ & $\mathrm{P}$ \\
\hline \multirow[t]{4}{*}{ Tourism } & Restourant & $\mathrm{R}$ & $\mathrm{R}$ & $\mathrm{R}$ \\
\hline & Bar/Night Club & $\mathrm{R}$ & $\mathrm{R}$ & $\mathrm{R}$ \\
\hline & Cafe & $\mathrm{R}$ & $\mathrm{R}$ & $\mathrm{R}$ \\
\hline & Hotel & $\mathrm{R}$ & $\mathrm{R}$ & $\mathrm{R}$ \\
\hline \multirow[t]{2}{*}{ Settlement } & Store Room & $\mathrm{P}$ & $\mathrm{P}$ & $\mathrm{P}$ \\
\hline & Garage & $\mathrm{P}$ & $\mathrm{P}$ & $\mathrm{P}$ \\
\hline \multirow{5}{*}{$\begin{array}{l}\text { Trade and Ser- } \\
\text { vices }\end{array}$} & Office Management & $\mathrm{R}$ & $\mathrm{C}$ & $\mathrm{C}$ \\
\hline & Supermarket & $\mathrm{R}$ & $\mathrm{R}$ & $\mathrm{R}$ \\
\hline & Shop & $\mathrm{R}$ & $\mathrm{R}$ & $\mathrm{C}$ \\
\hline & Fast Food Oulets & $\mathrm{R}$ & $\mathrm{R}$ & $\mathrm{C}$ \\
\hline & Warehouse/Pantry & $\mathrm{C}$ & $\mathrm{C}$ & $\mathrm{C}$ \\
\hline Recreation & Cinema & $\mathrm{R}$ & $\mathrm{R}$ & $\mathrm{C}$ \\
\hline Facilities & Gymnasium & $\mathrm{R}$ & $\mathrm{R}$ & $\mathrm{C}$ \\
\hline Trasportation & Parking Lot & $\mathrm{C}$ & $\mathrm{C}$ & $\mathrm{C}$ \\
\hline
\end{tabular}

Based on the results of content analysis, stakeholder essentially provided opportunity for underground building to be built in Kuta, but with more concern narrowed to suitability and carrying capacity of its environment and local cultures. Underground space was an alternative space in tourism development, but not all areas within Kuta able to be developed as a sustainable tourism space. The development control of under the ground building is most stringent in the low suitability zone where almost all functions are prohibited to be developed. There were changes in the 
intital matrix to accommodate stakeholder perspectives as seen in table 4. These changes are as mentioned below:

1. Low Suitability Zone was a prohibitted zone for activities, except for utilities and parking lot that could be carried out in the zone beyond the coastal border, but with certain limitations and requirements

2. Development of tourism accommodation permitted to be conducted in the high suitability zones but limitated to outside of the Tahura Ngurah Rai, open green spaces, equipped with mitigation system, were not activities which caused mass concentration of people and harmonius with their aboveground activities. This change was the major change of initial matrix. Tourism accommodations were the most significant space function to the development of Kuta as tourism region. Utilized under ground building to support above ground activities, especially as tourism accommodations, would make Kuta a better tourism region by henced the opportunity to create more open space above the ground.

The final concept of underground space development control in Kuta can be seen in table 4. The final concept of underground development control in Kuta is the underground space delopment control to create sustainable tourism region of Kuta. This concept emphasized its development control to be able to enhanced tourism quality in Kuta.

Table 4. Concept of Underground Space Development Control Based On Traditional Spatial Planning of Bali with Sustainable Development Approach in Traditional Village of Kuta

\begin{tabular}{ccccc}
\hline \multirow{2}{*}{$\begin{array}{c}\text { Space Func- } \\
\text { tion }\end{array}$} & $\begin{array}{c}\text { Type of Undegrouns } \\
\text { Space Activity }\end{array}$ & $\begin{array}{c}\text { Low Suita- } \\
\text { bility Zone }\end{array}$ & $\begin{array}{c}\text { Moderate Sui- } \\
\text { tability Zone }\end{array}$ & $\begin{array}{c}\text { High Suitability } \\
\text { Zone }\end{array}$ \\
\hline Utility & Power and Electricity & $\mathrm{L}$ & $\mathrm{P}$ & $\mathrm{P}$ \\
& Telecomunication & $\mathrm{L}$ & $\mathrm{P}$ & $\mathrm{P}$ \\
& Drainage & $\mathrm{L}$ & $\mathrm{P}$ & $\mathrm{P}$ \\
& Waste Water & $\mathrm{L}$ & $\mathrm{P}$ & $\mathrm{P}$ \\
Tourism & Gas & $\mathrm{L}$ & $\mathrm{P}$ & $\mathrm{P}$ \\
& Restourant & $\mathrm{R}$ & $\mathrm{R}$ & $\mathrm{C}$ \\
& Bar/Night Club & $\mathrm{R}$ & $\mathrm{R}$ & $\mathrm{C}$ \\
Settlement & Cafe & $\mathrm{R}$ & $\mathrm{R}$ & $\mathrm{C}$ \\
Trade and & Hotel & $\mathrm{R}$ & $\mathrm{R}$ & $\mathrm{R}$ \\
Services & Store Room & $\mathrm{P}$ & $\mathrm{P}$ & $\mathrm{P}$ \\
& Garage & $\mathrm{P}$ & $\mathrm{P}$ & $\mathrm{P}$ \\
& Office Management & $\mathrm{R}$ & $\mathrm{C}$ & $\mathrm{C}$ \\
& Supermarket & $\mathrm{R}$ & $\mathrm{R}$ & $\mathrm{R}$ \\
Recreation & Shop & $\mathrm{R}$ & $\mathrm{R}$ & $\mathrm{C}$ \\
Facility & Fast Food Oulets & $\mathrm{R}$ & $\mathrm{R}$ & $\mathrm{C}$ \\
Transportation & Warehouse/Pantry & $\mathrm{R}$ & $\mathrm{C}$ & $\mathrm{C}$ \\
& Cinema & $\mathrm{R}$ & $\mathrm{R}$ & $\mathrm{R}$ \\
& Gymnasium & $\mathrm{R}$ & $\mathrm{R}$ & $\mathrm{C}$ \\
& Parking Lot & $\mathrm{C}$ & $\mathrm{C}$ & $\mathrm{C}$ \\
\hline Source: Analysis Result, 2014 & & \\
\hline
\end{tabular}


As seen in Tabel 4, activities that allowed to be built under the ground are acitivites that supporting above ground activities and not generate mass concentration of people. Underground development control in Table 4 purposed to bring equality for future generations to earn the same benefits of underground space utilization as our generations.

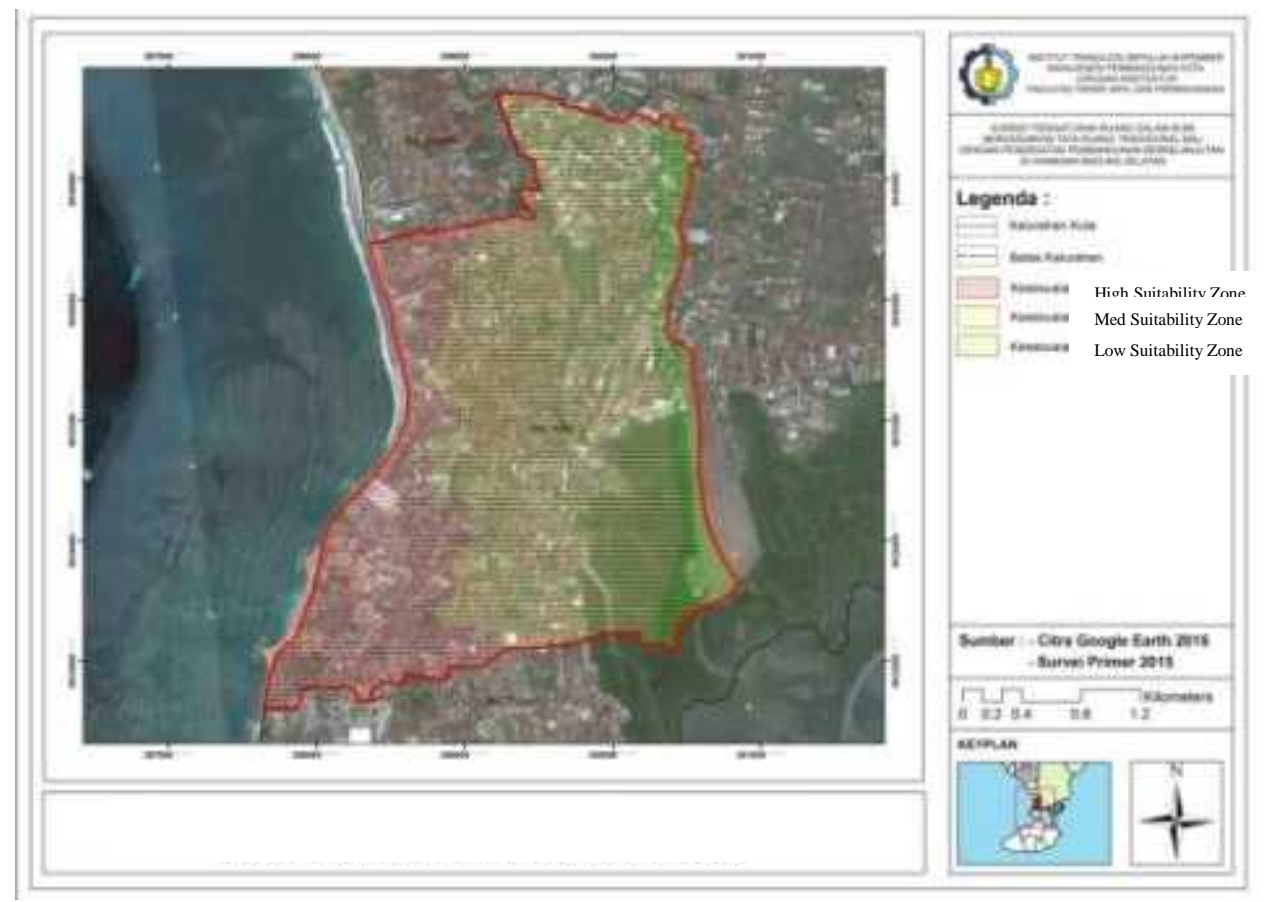

Figure 5. Map of Concept of Underground Space Development Control In Kuta Source: superimpose analysis result, 2014

\section{CONCLUSIONS}

1. Activities that conducted under the ground in Kuta largely were commercial activies (mostly hotels) functioned as parking lot. But there were also other commercial activities such trade and services that utilized the underground space as a mix function. This mix function combines the functions of more than single activity in underground space such as parking spaces for shopping space, management offices, praying room and modern shops in one space. The distribution of activities in underground space were concentrated along three streets; Legian Street, Kartika Plaza Street and Pantai Kuta Street.

2. Cultural suitability of underground space development in Kuta could not be evaluated using awig-awig of Kuta. There for status of underground space development in Kuta was unidentified and more relied on its environment suitability. Cultural justification of this kind of development was using locational approach related to Kawasan Tempat Suci, Kawasan Suci and Setra.These areas were sa- 
cred areas for Hindu and tradition's activities. Awig-awig of Kuta regulated a strict development inside of Kawasan Tempat Suci, Kawasan Suci and Setra that made development beyond of Hindu's activities were not allowed inside of these areas.

3. Undeground Space development in Kuta has a great impact on:

a. Excalation number of groundwater consumption

b. disruption of groundwater flow

c. Excalation quantities of wastewater production

d. Evoke a new transportation generator

Based on environment suitability analysis, there were 3 zones that divided Kuta based on its resilience and suitability. These zones as mentioned below.

a. Low Suitability zone. This zone has the highest risk of flooding, highest risk of tsunami, low earthquake risk, highest risk of abrasion, Kawasan Suci, Kawasan Tempat Suci, and Setra. The underground space development in this zone faced highest risk to disaster especially for human activites. This condition prohibited underground development for human activities at all scales but still possible for utilities. Restriction for human activities under the ground in this zone also served as mitigation system in Kuta.

b. Medium suitability zone. Half of this zone was stand on high risk of flooding area makes underground buildings inside this zone for human activities were vulnerable to be built. There were Kawasan Suci and Setra located in this zone made underground development limited to outside these sacred areas. But in other hand this zone has medium risk of tsunami and low risk of earthquake. Potential risk to natural disaster were lower then the Low Suitability Zone. Underground developments were possible in this zone but with some restrictions such: equipped with mitigation system, outside Kawasan Tempat Suci and Setra, and the activities were not the potential activities which caused mass concentration of people.

c. High suitability zone. This zone has low risk of earthquake, medium risk of tsunami and free from potential of flooding. Underground development in this zone has highest possibility to be built but most parts of this zone were part of Tahura Ngurah Rai as the green open space of Kuta. Any developments inside of Tahura Ngurah Rai were prohibited to maintain its function as water catchment area. That space limitation caused this zone has low potential to be built even it faced lowest risk of disaster

4. Main criterias of underground space development control in Kuta, based on stakeholder perspetives are as follow:

a. Evironment Criteria:

1) Located just outside of Green Open Space

2) Located just outside of Tahura Ngurah Rai

3) Located just outside of the Coastal Border Region

4) Equipped with mitigation system.

b. Culture Criteria: 
1) Underground space development are out and not directly adjacent to $\mathrm{Ka}$ wasan Tempat Suci

2) Underground space development are out and not directly adjacent to $\mathrm{Ka}$ wasan Suci

3) Underground space development are out and not directly adjacent to Setra

5. The concept of underground development control in Kuta is the underground space delopment control to create sustainable tourism region of Kuta. This concept emphasized the underground space development control to be able to enhanced tourism quality in Kuta. With this concept, the underground space utilization in Kuta could be monitored so as to created new space to support their above ground activities as they were difficult to grown laterally and upwards.

\section{REFERENCES}

Dwijendra, Ng. K. A. (2003), Perumahan dan Permukiman Tradisional Bali, Jurnal Permukiman "Natah", 1(1), page 8-24, Denpasar.

Suartika, G. A. M. (2010), Substansi Budaya Dalam Kebijakan Tata Ruang Di Bali, Humaniora, 22(3), 313-326, Denpasar

Kass, J. and Lees, D. (1997), Planning The Underground, Technical Paper Underground Space in The Urban Environment Development and Use, The Warren Centre for Advanced Engineering, The University of Sydney, Sidney.

Pinzone, T. et al (1997), Enviromental Implications of underground Space Development and Use, Technical Paper Underground Space in The Urban Environment Development and Use, The Warren Centre for Advanced Engineering The University of Sydney, Sidney.

Godard, J. P. (2004), Urban Underground Space and Benefits of Going Underground, presented at World Tunnel Congress 2004 and 30th ITA General Assembly - Singapore, 22-27 May 2004. 